
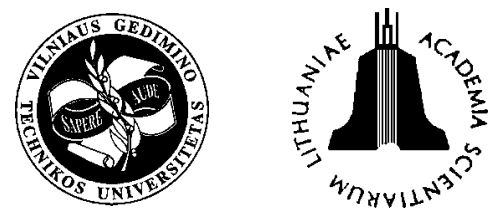

JOURNAL OF CIVIL ENGINEERING AND MANAGEMENT

http:/www.jcem.vgtu.lt

2004, Vol X, No 4, 249-253

\title{
INFLUENCE OF SOME TECHNOLOGICAL FACTORS UPON WALL CERAMICS FROST RESISTANCE
}

\author{
Michał Bołtryk, Vadim Nikitin, Beata Backiel-Brzozowska \\ Biatystok Technical University, Institute of Civil Engineering, Wiejska 45E Street, 15-351, Biatystok, Poland. \\ Tel.48 85 7469622. E-mail: bbb@pb.bialystok.pl
}

Received 3 Aug 2004; accepted 12 Nov 2004

\begin{abstract}
A polynomial model, which enables evaluation of the influence of amount and graining of sand in a ceramic mix and maximum temperature and duration of burning upon ceramics frost resistance, constructed on the basis of experimental results is presented in this work. During the experiment the mass loss of ceramic specimens was measured. Experimental results were prepared for further statistical analysis with regard to linear summing of mass losses. Statistical evaluation of the quality of the constructed model and physical interpretation of tested factors were made. In addition, the authors presented the results of the samples bulking investigation in comparison with the results of frostresistance test. Also the correlation of the results of both investigations was checked.
\end{abstract}

Keywords: building ceramics, experimental-statistical models, burning process, ceramic mix composition, frost resistance, water bulking.

\section{Introduction}

The durability of wall ceramic products exposed to an external environment can be determined on the basis of their frost resistance. Frost resistance is measured for a material totally saturated with water, subjected to destructive powers occurring during multiple freezing and thawing. It depends on many factors, among which the most important one is related to the porous capillary structure of material. This opinion is shared by many researchers who examine the durability of building materials $[1-3$, etc]. The better the material structure compensates unfavourable action of internal transfer of humidity in the form of gas, liquid and solid, the higher the material frost resistance is. The composition of the ceramic mix and parameters of the burning process significantly influence the porous structure of the material. Quantitative evaluation of these factors upon material frost resistance would allow forecasting this feature.

This paper presents a polynomial model which allows quantitative evaluation of the influence of quartz sand in a ceramic mix (amount and graining) interacting with the maximum temperature and the duration of the burning process upon frost resistance of wall ceramics. Parameters of the model were evaluated by comparison with experimental data.

\section{Characteristics of the tested object}

The test was carried out under laboratory conditions with cubic specimens $\left(125 \mathrm{~cm}^{3}\right)$ wet-molded from plas- tic mix using press. The mix was of plastic clay from the ceramic factory "Lewkowo" and contained local river sand. It represented a fusible clay with a melting point of about $1200{ }^{\circ} \mathrm{C}$ and sintering range $50-60{ }^{\circ} \mathrm{C}$. It is used for wall ceramics articles. It mostly contains the finest fraction - grains smaller than $10 \mu \mathrm{m}$ make up to $88 \%$ of its total mass and grains smaller than $2 \mu \mathrm{m}$ from 50 to $60 \%$. The specific surface of dry clay is $128 \mathrm{~m}^{2} / \mathrm{g}$. The main clay mineral is illite (hydromica), which includes minerals from chlorite and montmorillonite groups or laminar minerals (illite-montmorillonite). The chemical composition of clay in the form of percentage of oxides is as follows: $\mathrm{SiO}_{2}-46-48 \% ; \mathrm{Al}_{2} \mathrm{O}_{3}-14-17 \%$; $\mathrm{Fe}_{2} \mathrm{O}_{3}+\mathrm{FeO}-6,1-7,4 \% ; \mathrm{CaO}-9-10 \% ; \mathrm{MgO}-3,6-$ $4,1 \% ; \mathrm{K}_{2} \mathrm{O}+\mathrm{Na}_{2} \mathrm{O}-3,8-4,6 \%$. Roasting weight loss is $12,5-13,1 \%$. The amount of free quartz $\left(\mathrm{SiO}_{2}\right)$ is about $10 \%$.

The clay is susceptible to swelling during burning $[4,5]$ because the main clay mineral is hydromica, the finest grains make up the majority in grain size distribution, there is a high content of $\mathrm{Fe}_{2} \mathrm{O}_{3}+\mathrm{FeO}, \mathrm{K}_{2} \mathrm{O}+\mathrm{Na}_{2} \mathrm{O}$ and a low content of free $\mathrm{SiO}_{2}$ and a high roasting weight loss. During heating of hydromica clay, at the end of dehydration process, when incomplete burning of organic intrusions at $700{ }^{\circ} \mathrm{C}$ takes place, small stains in the liquid phase are formed between illite laminae. Formation of liquid phase in crystal lattice of hydromica is explained by presence of potassium, magnesium and ferric ions. Illite-like structures preserve their features during heating up to $1000{ }^{\circ} \mathrm{C}$, and when temperature reaches 
$1100^{\circ} \mathrm{C}$, ferric and magnesium spinels are formed and further precipitation of the liquid phase (or liquid-like phase) takes place $[4,6]$. With the temperature increase up to $1200^{\circ} \mathrm{C}$ spinels may disappear or pass to mullite. This description presents the character of main changes occurring in clay and hydromica during burning.

The correcting admixture in the form of quartz sand (containing approximately $0,3 \%$ of very small marl grains) has been introduced in order to regulate technical properties of clay. The majority $(96 \%)$ of sand grains is in the range of 0,06 to $1 \mathrm{~mm}$. The shape of grains is spherical. Approximately $67 \%$ of these grains is in the range of 0,25 to $1 \mathrm{~mm}$. This sand is qualified as medium-grain sand. Unfortunately, there is no unity of options about the desired grain size distribution of sand in literature. According to Avgustinik [4] it is advisable to apply medium-grain sand $(0,25-0,5 \mathrm{~mm})$, but according to Rogovoj [5] - coarse-grain sand (0,5-2 mm). However, both authors agree that dusty sands cannot be used in building ceramics.

\section{Estimation of damage moment in frost resistance examination}

Examination of ceramic material frost resistance was conducted on cubic specimens. Before freezing the specimens were saturated with water. Five sides of each cube were covered with rubber and thermal isolation. During cycles of freeze and thaw, heat transfer took place at the exposed surface of specimen. In this way a condition close to one-way frost action was created. Specimens saturated with water were frozen in an air-conditioned chamber to $-18^{\circ} \mathrm{C}$. Freezing time was not shorter than $4 \mathrm{~h}$. Specimens were thawed in temperature $20^{\circ} \mathrm{C}$. During thawing the exposed surface of each cube was under water. The duration of a freeze-thaw cycle was $24 \mathrm{~h}$.

The number of cycles of one side or volume freezing-thawing, which causes the first damage, has to be determined in standard wall ceramics frost resistance examinations. The moment of damage is determined after the appearance of destruction in a form of peel, chip, delamination (course), or cracks on a surface. The first two types of damage are the main criteria in frost resistance examination. All forms of destruction present an inaccurate estimation of the actual damage moment.

In the investigation, processes of material destruction during cyclic freeze and thaw were estimated on the basis of weight loss, caused by peeling and chipping. It was observed that the process of mass loss from the exposed surface of a specimen $\Delta \mathrm{m}\left(\mathrm{kg} / \mathrm{m}^{2}\right)$ has both a linear and a non-linear character. The widely known principle of linear summing of mass losses $[6,7]$ is valid up to $\Delta \mathrm{m} \approx 0,25 \mathrm{~kg} / \mathrm{m}^{2}$. Further cyclic action of temperature led very quickly to the total destruction of specimens.

The principle of linear summing of mass losses from the exposed surface of a material during cyclic freezing and thawing can be mathematically formulated as:

$$
\Delta m=c \cdot N,
$$

where $\mathrm{c}=$ empirical coefficient of proportionality, which characterises the intensity of mass loss of examined specimens; $\mathrm{N}=$ number of freeze-thaw cycles.

The correctness of the principle of linear summing of mass losses in a specified range is confirmed by data presenting the results of frost resistance examinations of ceramic material from different clays [8].

The maximum value of linear summing of mass losses from the exposed surface of specimens $\Delta \mathrm{m}_{\mathrm{tr}}=$ $0,2 \mathrm{~kg} / \mathrm{m}^{2}$ was accepted in the present study. The moment of sample damage corresponded with a number of freeze-thaw cycles causing a mass loss from the exposed surface of a specimen equal to or a little higher than the accepted threshold value $\Delta \mathrm{m} \geq \Delta \mathrm{m}_{\text {tr. }}$. After comparing 11 pairs of specimens (a control one and one subjected to freezing-thawing cycles to $\Delta \mathrm{m}_{\mathrm{tr}}$ ) it was observed that the mean loss of compressive strength of examined ceramic materials was $7 \%$.

\section{Model, experimental design and results}

The main features of ceramic materials are determined to a great extent by phase composition and porous structure, which is formed as a result of complex and often unidentified processes occurring in a ceramic mix during burning. Quartz sand plays a particular role in all these processes. It has been stated [9] that coarse quartz grains cannot react during heating and after burning quartz is partially not changed. Very fine quartz grains react in whole and they are a part of liquid phase. The author of work [10] also noticed that crystalline silica grains do not take part in forming liquid phase and they only undergo polymorphic transformation. According to [11], shrinkage of quartz related to volume changes during phase transition is so great that quartz grains remain separated from liquid phase. Probably it is the reason why the decrease of compressive strength and the increase of porosity of ceramic products are observed.

Such unclear description of effects of the above phenomena allows formulating only some of premises, which should be considered while selecting mathematical models connecting in a quantitative way material features with amount and graining of sand in interaction with burning parameters. The number of input quantities (independent quantities) and scale (the level of variation of tested factors), which are the base of experimental design, should be established before selection of mathematical model.

It has been assumed that the burning process is characterised by two factors: $\mathrm{X}_{1}-$ maximum burning temperature, $X_{2}$ - duration of burning at maximum temperature. As known, the relation between ceramic properties and burning regimes is not linear. That is why parabolic dependency has been used. Factors $X_{1}$ and $X_{2}$ varied on three levels (lower, medium and upper): 900, 990, $1080{ }^{\circ} \mathrm{C}\left(\mathrm{X}_{1}\right) ; 1,2,3$ hours $\left(\mathrm{X}_{2}\right)$. At the same time the rate of increasing and decreasing the temperature was 
constant $\left(3^{\circ} \mathrm{C} / \mathrm{min}\right)$. The total duration of burning was 10,$8 ; 12,5$ and 14,2 hours respectively. The third variable $\mathrm{X}_{3}$ was the content of sand in the ceramic mix: 5, $15,25 \%$ (by weight). Sand was composed of three fractions: fine-grained $Z_{1}$ (grains up to $0,25 \mathrm{~mm}$ ), mediumgrained $Z_{2}(0,25-0,5 \mathrm{~mm})$ and coarse-grained $Z_{3}(0,5-$ $1,0 \mathrm{~mm})$. The condition $\Sigma Z_{\mathrm{i}}=1$ was satisfied at variation of grain-size (mass) factors $Z_{1}, Z_{2}$ and $Z_{3}$.

Dependency of frost resistance on technological factors $\mathrm{X}_{1}, \mathrm{X}_{2}$ and $\mathrm{X}_{3}$ was described by a second-order polynomial:

$$
\begin{aligned}
& F R=b_{0}+b_{1} x_{1}+b_{2} x_{2}+b_{3} x_{3}+b_{12} x_{1} x_{2}+b_{13} x_{1} x_{3}+ \\
& b_{23} x_{2} x_{3}+b_{11} x_{1}^{2}+b_{22} x_{2}^{2}+b_{33} x_{3}^{2},
\end{aligned}
$$

where

$x_{1}=\left(X_{i}-990\right) / 90 ; x_{2}=X_{2}-2 ; x_{3}=\left(X_{3}-15\right) / 10-$ are coded (non-dimensional) factors, which have equal levels in experimental design: -1 (lower), 0 (medium), 1 (upper). $\mathrm{X}_{\mathrm{i}}$ is a natural value of input quantity.

All coefficients of polynomial (2) are functions dependent on grain-size factors $Z_{i}$ and they are described by a reduced (incomplete) third-order polynomial:

$$
\begin{aligned}
& b_{(0, i, i j, i i)}=\beta_{1} Z_{1}+\beta_{2} Z_{2}+\beta_{3} Z_{3}+\beta_{12} Z_{1} Z_{2}+\beta_{13} Z_{1} Z_{3}+ \\
& \beta_{23} Z_{2} Z_{3}+\beta_{123} Z_{1} Z_{2} Z_{3}, \quad\left(i, j=1,2,3 ; b_{i j}, i<j\right) .
\end{aligned}
$$

It was expected that the accepted model $(2,3)$ should reflect all complex interactions between grain-size factors $Z_{\mathrm{i}}$ and technological factors $\mathrm{X}_{\mathrm{i}}$. In [12] that type of model was used to describe sorption humidity in ceramic brick and hardened cement mortar containing three types of salts. Literature gives also other examples of application of this model [13].

Composition-symmetrical experimental design containing 14 samples with different coded values of input quantity $X_{i}$ [14] was used in order to obtain experimental data necessary to evaluate coefficients of polynomial (2). Each point of this design was repeated seven times at different proportions of three sand fractions $Z_{i}$. These proportions were prepared according to simplex Scheffe's design, which is commonly used at experimental design of composition-feature type [14] and to analyse material technology problems. The clearest picture of the chosen experimental design can be obtained after consideration of data in Table. According to this design, at maximum randomisation, $\mathrm{N}=14 \times 7=98$ specimens were prepared.

When analysing experimental data in rows and columns in Table 1 it can be noticed that values of frost resistance change approximately two or three times. It may be concluded that at least some effects of factors $X_{i}$ and $Z_{i}$ are significant from the statistical point of view.

\section{Statistical analysis of experimental results}

Each column of experimental data in Table was analysed. Each column contains results of frost resistance tests of specimens with the same grain-size distribution

\begin{tabular}{|c|c|c|c|c|c|c|c|c|c|}
\hline \multicolumn{3}{|c|}{$\begin{array}{l}\text { Technological } \\
\text { factors }\end{array}$} & \multicolumn{7}{|c|}{$\begin{array}{l}\text { Frost resistance (cycle number) } \\
\text { at different sand composition (fractions } Z_{1} \text {, } \\
Z_{2}, Z_{3} \text { mixed of equal proportions) }\end{array}$} \\
\hline $\begin{array}{c}\mathrm{X}_{1} \\
{\left[{ }^{\circ} \mathrm{C}\right]}\end{array}$ & $\begin{array}{l}\mathrm{X}_{2} \\
{[\mathrm{~h}]}\end{array}$ & $\begin{array}{c}\mathrm{X}_{3} \\
{[\%]}\end{array}$ & $Z_{1}$ & $Z_{2}$ & $\mathrm{Z}_{3}$ & $\begin{array}{l}Z_{1} \\
Z_{2}\end{array}$ & $\begin{array}{l}Z_{1} \\
Z_{3}\end{array}$ & $\begin{array}{l}Z_{2} \\
Z_{3}\end{array}$ & $\begin{array}{l}Z_{1} \\
Z_{2} \\
Z_{3}\end{array}$ \\
\hline 1080 & 1 & 5 & 44 & 32 & 25 & 32 & 40 & 32 & 30 \\
\hline 900 & 1 & 5 & 22 & 12 & 11 & 14 & 21 & 18 & 14 \\
\hline 1080 & 3 & 5 & 50 & 42 & 30 & 40 & 40 & 40 & 42 \\
\hline 900 & 3 & 5 & 24 & 15 & 13 & 14 & 14 & 19 & 18 \\
\hline 1080 & 1 & 25 & 56 & 43 & 32 & 48 & 45 & 36 & 44 \\
\hline 900 & 1 & 25 & 28 & 20 & 19 & 23 & 18 & 15 & 18 \\
\hline 1080 & 3 & 25 & 56 & 44 & 29 & 47 & 42 & 32 & 44 \\
\hline 900 & 3 & 25 & 35 & 23 & 16 & 22 & 17 & 16 & 18 \\
\hline 900 & 2 & 15 & 22 & 17 & 14 & 23 & 19 & 15 & 18 \\
\hline 1080 & 2 & 15 & 53 & 42 & 30 & 45 & 40 & 39 & 42 \\
\hline 990 & 1 & 15 & 45 & 36 & 20 & 37 & 28 & 26 & 27 \\
\hline 990 & 3 & 15 & 38 & 32 & 21 & 33 & 28 & 30 & 25 \\
\hline 990 & 2 & 5 & 35 & 27 & 24 & 29 & 30 & 28 & 24 \\
\hline 990 & 2 & 25 & 52 & 38 & 21 & 39 & 26 & 25 & 33 \\
\hline
\end{tabular}
of sand and prepared at different levels of factors $\mathrm{X}_{1}$,
Experimental design and experimental results of ceramic specimens frost resistance

$\mathrm{X}_{2}$ and $\mathrm{X}_{3}$. Regression equations in the form of secondorder polynomial were determined for each column and than they were analysed and interpreted. Residuals of each equation were determined basing on Daniel's method [15] in the form of empiric distribution function. The residuals were determined as a difference between empirical and theoretical value of frost resistance. As an example, the residuals distribution of one model formulated basing on data presented in one column, $Z_{1}=1$ are shown in Fig 1. The residuals are approximately in accordance with normal distribution and standard devia-

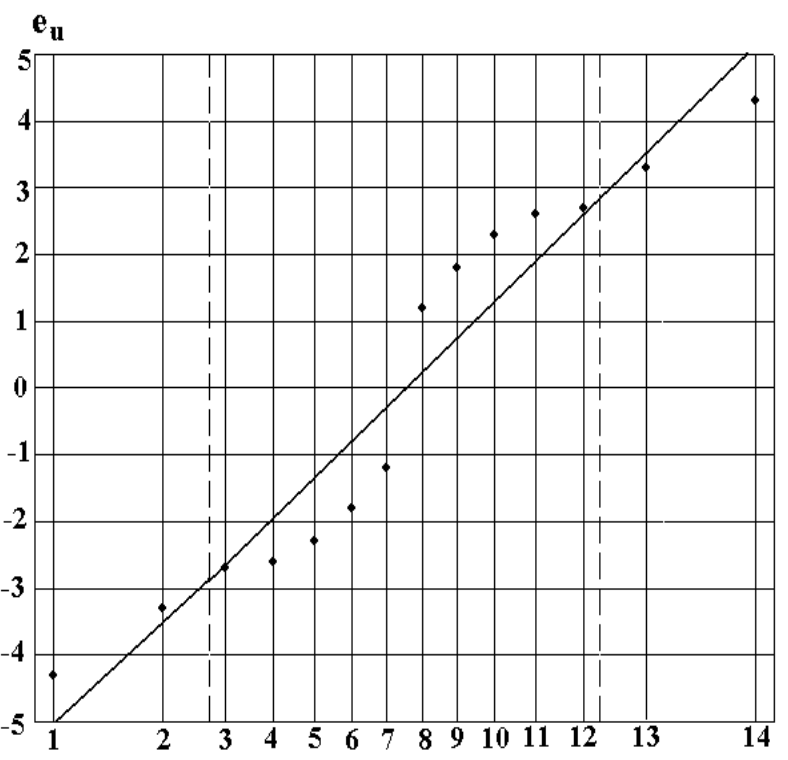

Fig 1. Empirical cumulative distributions function of residuals (model of frost resistance for ceramic material consisting of only fine-grained sand $-Z_{1}$ ) 
tion equals approximately 2,9, based on 4 degrees of freedom. Mean standard deviation for the family of models equals 2,67 (28 degrees of freedom).

Then, at the selected significance level $\alpha=0,05$ and at experimental error $s_{F R}^{2}=7,15$ according to Student's t-test criterion $\left(\mathrm{t}_{0,05 ; 28}=2,05\right)$, statistically significant regression coefficients of equation (2) were determined. After approximation of coefficients of model (2) by polynomial (3), the final model for defining frost resistance of specimens was found:

$$
\begin{aligned}
& F R=42,5 Z_{1}+33,3 Z_{2}+21,8 Z_{3}-13,6 Z_{1} Z_{2}- \\
& 12,2 Z_{1} Z Z_{3}-4,2 Z_{2} Z_{3}-21,6 Z_{1} Z_{2} Z_{3}- \\
& \left(12,8 Z_{1}+11,6 Z_{2}+7,3 Z_{3}-2,4 Z_{1} Z_{2}+\right. \\
& \left.7,0 Z_{1} Z_{3}+12,3 Z_{1} Z_{2} Z_{3}\right) x_{1}+ \\
& \left(5,2 Z_{1}+4,0 Z_{2}+1,4 Z_{3}+1,6 Z_{1} Z_{2}-\right. \\
& \left.13,2 Z_{1} Z_{3}-10,8 Z_{2} Z_{3}+50,1 Z_{1} Z_{2} Z_{3}\right) x_{3}+ \\
& \left(-3,5 Z_{1}-+4,3 Z_{2}+7,0 Z_{1} Z_{3}+\right. \\
& \left.8,5 Z_{2} Z_{3}+21,2 Z_{1} Z_{2} Z_{3}\right) x_{1}^{2}
\end{aligned}
$$

According to the model (4), frost resistance of ceramic material achieves the highest results are $x_{1}=+1$ and $x_{3}=+1$. After calculating values of frost resistance for every possible combination of coded value of technological factors $\mathrm{x}_{1}$ and $\mathrm{x}_{3}$, it was obtained that optimum conditions for technological factors are when maximum burning temperature is $1080{ }^{\circ} \mathrm{C}$ and $25 \%$ of sand is added to a ceramic mix. After substitution of coded values for model (4) the following equation was obtained:

$$
\begin{aligned}
& F R_{\text {opt }}=57 Z_{1}+45 Z_{2}+30,5 Z_{3}-14,4 Z_{1} Z_{2}- \\
& 11,4 Z_{1} Z_{3}-6,5 Z_{2} Z_{3}+62 Z_{1} Z_{2} Z_{3} .
\end{aligned}
$$

Equation (5) allows calculating the maximum value of frost resistance (optimum condition) for the specific grain-size distribution of sand. Geometrical picture of dependency (5) in the form of isolines of frost resistance on tricomponent diagram is presented in Fig 2.

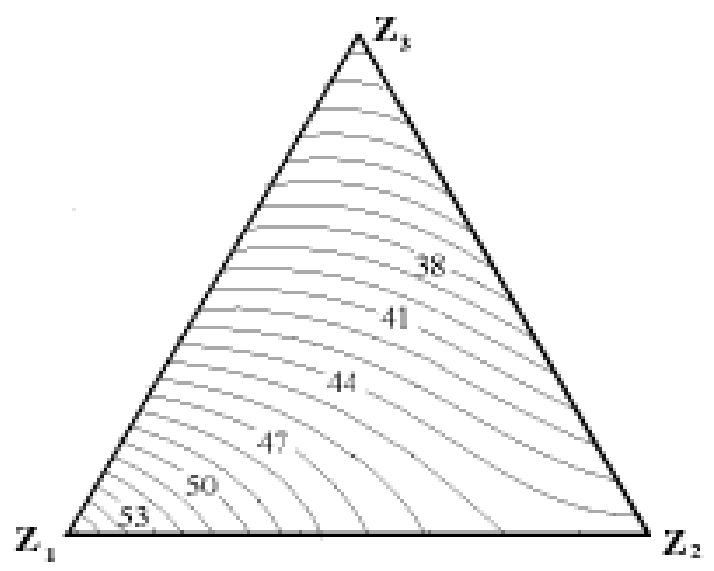

Fig 2. Isolines of ceramic material frost resistance on tricomponent diagram of grain-size distribution of sand for optimum technological conditions
According to this diagram, specimens with fine-grained sand (grains up to $0,25 \mathrm{~mm}$ ) achieve the highest frost resistance (55 cycles). Specimens with gross-grained sand $(0,5-$ $1,0 \mathrm{~mm})$ are characterised by almost twice lower frost resistance (30 cycles).

\section{Evaluation of the frost resistance on the base of the ceramic materials bulking in water}

There is an opinion in literature that frost resistance of the ceramic materials may be forecast on the base of the samples' volume changes with the water saturation $[16,17]$. For the sake of simplicity of the procedure and much shorter time needed to carry out the investigation of the samples bulking in water in comparison with the investigation of frost-resistance, the authors admitted to be advisable checking the correlation of the results of both investigations.

Investigation of the ceramic material bulking was carried out in laboratory terms on 24 cubic samples moulded of the ceramic mass containing $15 \%$ of the quartz-sand addition of the grain size composition $Z_{1}=Z_{2}=Z_{3}=0,33$. The samples were burned with the change of maximum temperature of the isothermal heat: $900{ }^{\circ} \mathrm{C}$ (7 samples), $990{ }^{\circ} \mathrm{C}$ (10 samples), $1080{ }^{\circ} \mathrm{C}(7$ samples). The speed of heating and cooling was constant $-3{ }^{\circ} \mathrm{C} / \mathrm{min}$. After burning the samples were kept in water for 10 days and the changes in linear dimensions were measured. Then the frost resistance was investigated according to the method described in the article.

During the investigation there was noticed that after 7-8 days of keeping in water the bulking of samples has stopped. In further analysis there was taken into account the maximal bulking of the samples. The numerical value of this indicator has decreased with increasing the temperature of samples burning. The measurement results of the samples' linear dimensions changes and the frostresistance of 24 samples were shown in Fig 3, where one can see that the frost-resistance of samples increase when their bulking in water decrease approximately in

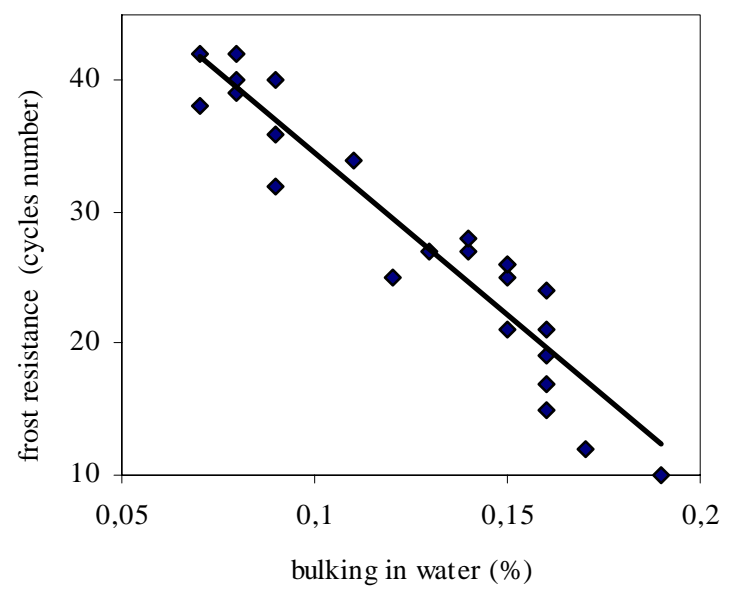

Fig 3. Relation between the results of frost resistance test and bulking in water test 
linear dependence. The precision of the linear dependence between the values of those indicator/indexes characterises the negative correlation factor equal to 0,946 .

The presented dependency may be the base to work out the method of frost resistance evaluation of the ceramic samples on the basis of the materials bulking in water indicator. The estimation of stability of dependence between indicators requires carrying out special investigations.

\section{Conclusions}

1. The experiment proved that not only parameters of the burning process and the sand content influence frost resistance of wall ceramics. Also, the grain-size distribution of sand has an impact on ceramics performance.

2. Formulated statistical-experimental models describe with sufficient accuracy results of a very complex mutual interaction between the considered factors; they allow solving different engineering problems, such as the prediction of the durability of a ceramic material.

3. The interdependence of frost resistance and bulking in water of ceramic material was confirmed.

The experiment was carried in Bialystok Technical University in the frame of Projects No W/IIB/1/03 \& S/ IIB/1/02 supported by State Committee for Scientific Research.

\section{References}

1. Bochen, J. Assessment of the durability of mineral faēade plasters on the ground of the porosity variations in accelerated ageing environment (Ocean trwałości mineralnych tynków elewacyjnych na podstawie zmiany ich porowatości w warunkach przyśpieszonego starzenia). In: Proceedings of the 9th Scientific-technical conference „Physics of building in theory and practice (Fizyka budowli w teorii $\mathrm{i}$ praktyce)". Łódź, 2003, p. 64-71 (in Polish).

2. Żygadło, M. \& Piasta, Z. Forecasting of building ceramics frost resistance on the ground on their capillary properties (Prognozowanie mrozoodporności ceramicznych materiałów budowlanych na podstawie ich właściwości kapilarnych). Engineering and building industry (Inżynieria i Budownictwo), Vol 2. Warszawa, 1989, p. 56-57 (in Polish).

3. Zhang, B. Relationship between pore structure and mechanical properties of ordinary concrete under bending fatigue. Cement and concrete research, Vol 27, No 8, 1997.

4. Avgustinik, A. I. Ceramics (Ceramika). Warszawa: Arkady, 1980 (in Polish).
5. Rogovoj, M. I. Technology of artificial pore aggregates and ceramics (Технология искусственных пористых заполнителей и керамики). Moscow: Strojizdat, 1974 (in Russian).

6. Kartašov, G. D. Methods of material examinations (Методы форсированных испытаний). Moscow: Znanie, 1979, p. 56-98 (in Russian).

7. Nikitin, V. \& Lapko, A. Methods of service life predicting wall finishes in interior of monumental buildings (Metody oceny okresu przydatnośxci użytkowej elementów i wykończenia wnętrz w budowlach zabytkowych). In: Monumental Constructions, Proc. intern. symp. Białystok, Białystok Technical University, 1998, p. 198-204 (in Polish).

8. Zelikin, S. I. \& Zemlanski, V. N. \& Civilev, R. P. Examination of material destruction kinetics using x-ray method (Исследование кинетики разрушения материалов рентгено-графическим методом). Glass and ceramics (Стекло и керамика), Vol 6, Moscow, 1979, p. 23-24 (in Russian).

9. Worrall, W. Clays and ceramic raw materials. London, 1980.

10. Peregudov, V. V. \& Pogovoj, M. I. Heating processes and installation of building articles and details technology (Тепловые процессы и установки в технологии строительных изделий и деталей). Moscow: Strojizdat, 1983 (in Russian).

11. Pavlov, V. F. Physical-chemical grounds of building ceramics burning (Физико-химические основы обжига изделий строительной керамики). Moscow: Strojizdat, 1977 (in Russian).

12. Nikitin, V. \& Guriev, V. \& Łapko, A. Modeling of sandwich concrete building structures production and service processes (Modelowanie procesów w produkcji i eksploatacji warstwowych konstrukcji budowlanych). Białystok Technical University, Białystok, 1999. 244 p. (in Polish).

13. Voznesenskij, V. A. \& Vyrovoj, V. N. \& Kerš, V. \& Ljašenko, T. V. Modern methods of composite materials optimization (Применение статистики в промышленном эксперименте). Kiev: Budivel'nik, 1983 (in Russian).

14. Nalimov, V. V. Experimental design tables for factor and polynomial models (Планы эксперимента для факторных полиноминальных моделей). Moscow: Metalurgija, 1982 (in Russian).

15. Daniel, K. Statistics in industrial experiment (Применение статистики в промышленном эксперименте). Moscow: Mir, 1979 (in Russian).

16. Kuzmin, I. D. \& Seljuk, G. P. \& Nikitina, O. I. \& Nikitin, V. I. Estimation of frost resistance of building ceramics (Оценка марозостойкости стеновой керамики). Building materials (Строительные материалы), Vol 4, 1980, p. 22-23 (in Russian).

17. Blicharski, M. Introduction in materials engineering (Wprowadzenie do inżynierii materiałowej). Warszawa: PWN, 1998 (in Polish). 